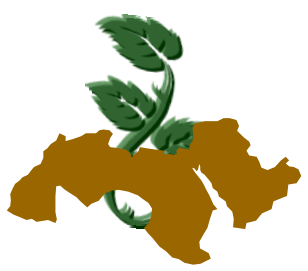

Arab Univ.

J. Agric. Sci., Ain Shams Univ., Cairo, 22(2), 371- 380, 2014

\title{
IMPACT OF DIFFERENT SOURCES OF NITROGEN FERTILIZERS ON PERFORMANCE GROWTH OF DATE PALM (Phoenix dactylifera L. cv. Bartomouda)
}

\author{
Eman M.M. Zayed'; Rasmia, S.S. Darwesh ${ }^{1}$; Amal F.M. Zein El-Din'1 \\ and Hala. M.A. Farrag ${ }^{1}$ \\ 1- Central Laboratory of Date Palm for Research and Development, Agric. Research \\ Center, Giza, Egypt
}

Keywords: Ammonium, Chlorophyll, Date palm, Growth, Indole, Nitrogen, Potassium and Sulfate

\section{ABSTRACT}

A green house experiment was carried out in two successive seasons on date Palm plantlets (Phoenix dactylifera L. cv. Bartomouda) from 2012 to 2013 , to evaluated the effectiveness of different sources of nitrogen fertilizer at four treatments as (T2) $5 \mathrm{~g} / \mathrm{l}$ ammonium sulfate $20 \%$ (1 g nitrogen), (T3) $3 \mathrm{~g} / \mathrm{l}$ potassium nitrate $33 \%$ ( $1 \mathrm{~g}$ nitrogen) and (T4) $2 \mathrm{~g} / \mathrm{l}$ urea (46\%) with the irrigation water one time/ week. The design of the experiment was randomized complete with three replicates. The results revealed that, plant height $\mathrm{cm}$, leaves numbers, root length $\mathrm{cm}$ and numbers, and fresh and dry weights of leaves and roots were increasing highly significantly with $3 \mathrm{~g} / \mathrm{l}$ of potassium nitrate graduated by $2 \mathrm{~g} / \mathrm{l}$ urea and $5 \mathrm{~g} / \mathrm{l}$ ammonium sulfate respectively at both seasons. Chlorophyll $a, b$ and carotenoids contents showed significant rising with $3 \mathrm{~g} / \mathrm{l}$ potassium nitrate. Greatest significant contents of indole and proline were obtained under T3 for two seasons. Leaves nitrogen content $\mathrm{N}$ was increased by $2 \mathrm{~g} / \mathrm{l}$ urea in the two seasons; on the other hand, root nitrogen content was increased with treatment $3 \mathrm{~g} / \mathrm{l}$ potassium nitrate, sequenced by T2 and T4 treatments. Leaves and roots phosphorus $\mathrm{P}$ content significantly raising under $3 \mathrm{~g} / \mathrm{l}$ potassium nitrate and $5 \mathrm{~g} / \mathrm{l}$ ammonium sulfate for two seasons. In the presence of $5 \mathrm{~g} / \mathrm{l}$ ammonium sulfate and $3 \mathrm{~g} / \mathrm{l}$ potassium nitrate leaves and root potassium content $K$ were largest at two seasons respectively. This research shows that the nitrogen formula as potassium nitrate > ammonium sulfate $>$ urea were recommended to highly increasing growth of date palm plantlets in the green house.

\section{INTRODUCTION}

Date palm (Phoenix dactylifera L.) yield and fruit quality are mostly dependant on cultivar, pollination, fertilization, and water relations (Iqbal et al 2004). Date palm is one of the oldest fruit trees in the world. It is known as "tree of life" because of its resilience, its need for limited water inputs, its long term productivity and its multiple purpose qualities. In Egypt, dates are important traditional crops. Egypt is considered as the first country of the top ten date producers $(1,130,000$ tones) FAO (2010). Huge reductions in soil minerals content must be compensated annually by good fertilization programs in order to maintain the high yield and good quality of dates. The use of chemical fertilizer is necessary for supplying the nutrient requirements. However, the continuous use of chemical fertilization leads to deterioration of soil characteristics and fertility as well as it might lead to the accumulation of heavy metals in plant tissues which contribute to fruit nutrition value and edible quality (Shimbo et al 2001). Quick-release sources are water-soluble (e. g., ammonium nitrate, urea, ammonium sulfate); they will release nitrogen into the soil solution rapidly with rainfall or irrigation, Ammonium $\left(\mathrm{NH}_{4}{ }^{+}\right)$and nitrate $\left(\mathrm{NO}_{3}{ }^{-}\right)$are the most important inorganic $\mathrm{N}$ sources in soils readily available to plants. For many plants, $\mathrm{NH}_{4}{ }^{+}$, when supplied solely at high concentrations, is toxic and impairs plant growth (Britto and Kronzucker 2002). The forms and levels of nitrogen, the cultivars and the physico-chemical properties of the soil are all related to the use of nitrogen by plants (Li et al 2007). 
Different growth characteristics were affected by different sources of nitrogen application as ammonium $\left(\mathrm{NH}_{4}^{+}\right)$, nitrate $\left(\mathrm{NO}_{3}^{-}\right)$and urea are the forms of nitrogen generally applied. Different nitrogen sources may be preferred for use with different plant species, The form of nitrogen applied can play a significant role in plant growth and productivity, Fertilizers are extremely important factors in determining horticultural crop yield, quality and nutritional content (Marschner 1995, MartinezBallestra et al 2008 and Sady et al 2008).

Nitrogen is the element in highest demand in terms of quantity and makes up about $2 \%$ to $3 \%$ of plant dry matter, Nitrate $\mathrm{NO}_{3}$ application increased leaves weight, plant growth, root/shoot ratio, total nitrogen uptake, the contents of leaves $\mathrm{N}, \mathrm{P}$ and $\mathrm{K}$ (Kim et al 2000 on pecan Carya illioensis, and Carrington et al $\mathbf{2 0 0 0}$ on Saw palmetto (Serenoa repens). Total $\mathrm{N}, \mathrm{P}, \mathrm{K}, \mathrm{Fe}, \mathrm{Mg}, \mathrm{Zn}$ and $\mathrm{Mn}$, amino acids leaves content, biomass increased by application of $\mathrm{NH}_{4}{ }^{+}+\mathrm{NO}_{3}$ (Ruan et al 2007 on Camellia sinensis $\mathrm{L}$ ). Ammonium sulfate, ammonium nitrate and urea at 350 to $1050 \mathrm{~g} /$ tree increased N, $\mathrm{P}$, and $\mathrm{K}$ leaves contents of date palm (Saleh, 2009 and Kassem, 2012). Potassium sulfate 3 $\mathrm{kg} /$ tree $\left(48 \% \mathrm{~K}_{2} \mathrm{O}\right)$ and potassium nitrate increased number of leaves of date palm cv. Kabkab and chlorophyll contents of peach (Abdi and Hedayat 2010 on date palm Phoenix dactylifera L. and Sarfaraz, 2010 on peach Prunus persica L. Cv. Early coronet)). $150 \mathrm{~kg} / \mathrm{ha}$ as urea increased plant height, leaves numbers shoot fresh and dry weights and total $\mathrm{P}$ in carrot Daucus carrota L. (Mehedi et al 2012). Therefore, the main object of this work was to determined the evaluated of different sources of nitrogen fertilizers on the growth of date palm under greenhouse condition.

\section{MATERIALS AND METHODS}

This work conducted to identify the effect of different sources of nitrogen fertilizer as ammonium sulfate, potassium nitrate and urea on the growth of date Palm plantlets (Phoenix dactylifera L. cv. Bartomouda) in two seasons 2012-2013 in the green house of Central Laboratory for Research and Development of Date Palm (ARC), Giza. These plantlets were achieved by tissue culture technique and subjected with treatments after 6 months from acclimatization stage and cultured in the plastic bags ( $40 \mathrm{~cm}$ length and $25 \mathrm{~cm}$ for width) which filled in peat moss + sand $2: 1$, the plantlets described as $(20-25 \mathrm{~cm}$ in length, $4-5$ leaves/ plantlet, 3-4 roots/plantlet and $30-35 \mathrm{~cm}$ for root length). All plantlets were subjected with four treatments of different nitrogen forms one time/week:

1- (T1) control treatment (tap water)

2- (T2) $5 \mathrm{~g} / \mathrm{l}$ ammonium sulfate $20 \% \mathrm{~N}$ (1 g nitrogen)

3- (T3) $3 \mathrm{~g} / \mathrm{l}$ potassium nitrate $33 \% \mathrm{~N}$ (1 g nitrogen)

4- (T4) 2 g/l urea (46\%)

The plantlets were received $0.5 \mathrm{~g} / \mathrm{l}$ potassium sulfate as $\mathrm{K}_{2} \mathrm{O}+0.5 \mathrm{~g} / \mathrm{l} \mathrm{P}_{2} \mathrm{O}_{5}$ as single super phosphate before three days from nitrogen treatments, plantlets were irrigated at two times per week., vegetative growth and chemical contents were determined after each seasons.

\section{Vegetative growth}

1- Plant height $(\mathrm{cm}) \quad 2$ - leaves numbers/plantlet

3- length $(\mathrm{cm})$ and number of roots

4- Fresh and dry weight of leaves and roots $(\mathrm{g})$

\section{Chemical contents}

1- Chlorophyll a,b and carotenoids

2- Indoles $\mathrm{mg} / \mathrm{g}$ f.w.

3- Proline $\mathrm{mg} / \mathrm{g}$ d.w.

4- N, P and K\%. leaves and roots contents

Chlorophyll as described by Lichtentaler and Wellburn (1985).

Indoles as according to Larsen et al (1962).

Proline as Bates et al (1973).

N, P and K as described by Jackson (1973).

Experimental design: Complete randomized block design with three replicates and three plantlets for each one, two growth seasons (8 months for each). Data were analyzed by analysis of variances (ANOVA) and the means were compared following $t$ - test using L.S.D. values at $5 \%$ level (Snedecor and Chocran 1980).

\section{RESULTS}

Vegetative characteristics of date palm plantlets plant height, leaves numbers, length and numbers of roots, fresh and dry weights of leaves and roots showed significant growth response to different sources of nitrogen fertilizers applications, ammonium sulfate $\mathrm{T} 2$, potassium nitrate $\mathrm{T} 3$ and urea T4.

\section{Plant height $\mathrm{cm}$}

Plants heights of date palm (Table 1) were varied significantly from 24.0 and $27 \mathrm{~cm}$ in control (tap water only) to 67.3 and $89.7 \mathrm{~cm}$ respectively for $1^{\text {st }}$ 
and $2^{\text {nd }}$ seasons in plants that received T3 potassium nitrate at $3 \mathrm{~g} / \mathrm{l}$ sequenced by (T4) $2 \mathrm{~g} / \mathrm{l}$ urea and (T2) $5 \mathrm{~g} / \mathrm{l}$ ammonium sulfate were recorded 65.0 and $84.7 \mathrm{~cm}$ and 57.3 and $70.0 \mathrm{~cm}$ respectively for two treatments and $1^{\text {st }}$ and $2^{\text {nd }}$ seasons.

\section{Leaves numbers}

Data of both seasons presented in (Table 1) elucidated that, significant increasing of leaves numbers /plantlet under different sources of nitrogen fertilizers at $1^{\text {st }}$ and $2^{\text {nd }}$ seasons, leaves numbers/plantlet of date palm were highly significant performed from 7.9 leaves/plantlet in $1^{\text {st }}$ season to 12.4 leaves/plantlet in the $2^{\text {nd }}$ season under (T3) 3 $\mathrm{g} / \mathrm{l}$ potassium nitrate followed by other nitrogen sources (T2) and (T4), fewer numbers of leaves were found with control treatment 5.0 and 6.3 leaves respectively in $1^{\text {st }}$ and $2^{\text {nd }}$ seasons.

\section{Root length $\mathrm{cm}$ and roots numbers}

The results on the effect of different nitrogen fertilizers treatments on root length are presented in (Table 1) illustrated, the superiority for significant longest roots with the treatment (T3) $3 \mathrm{~g} / \mathrm{l}$ potassium nitrate which produced 64.0 and $66.7 \mathrm{~cm}$ in the $1^{\text {st }}$ and $2^{\text {nd }}$ seasons respectively, graduated by (T2) ammonium sulfate $5 \mathrm{~g} / \mathrm{l}$ and (T4) $2 \mathrm{~g} / \mathrm{l}$ urea, these higher increment of root length not found with untreated plantlets (control treatment) which attained the shortest roots 28.3 and $35.1 \mathrm{~cm}$ in the $1^{\text {st }}$ and $2^{\text {nd }}$ seasons respectively. However, in the same trend the numbers of roots were significant increasing under (T3) treatments in the $1^{\text {st }}$ and $2^{\text {nd }}$ season, the plantlets were received (T4) $2 \mathrm{~g} / \mathrm{l}$ urea had left fewer number of roots at $1^{\text {st }}$ and $2^{\text {nd }}$ seasons respectively in compared to other nitrogen treatments.

\section{Fresh and dry weights of leaves and roots (g)}

The survey results cleared that, the plantlets leaves fresh and dry weights were differs between the treatments of different nitrogen sources (Table 2), the plantlets which received $\mathrm{T} 3 \mathrm{3g} / \mathrm{l}$ potassium nitrate scored the highest weights of leaves 6.7 and $7.4 \mathrm{~g}$ in $1^{\text {st }}$ and $2^{\text {nd }}$ respectively for fresh weight and 2.9 and $3.3 \mathrm{~g}$ in $1^{\text {st }}$ and $2^{\text {nd }}$ respectively for dry weights of leaves, significant differences between two other sources of nitrogen T2 $5 \mathrm{~g} / \mathrm{l}$ ammonium sulfate and T4 $2 \mathrm{~g} / \mathrm{l}$ urea on the fresh and dry weights of leaves, moreover, smallest fresh and dry weights of leaves were found under control treatment. Regarding to the different nitro- gen sources on the fresh and dry weights of roots (Table 2) clarified that, different supplements of nitrogen sources were significant performance fresh and dry weights of roots compared to control treatments, highly performance was obtained with T3 in $1^{\text {st }}$ and $2^{\text {nd }}$ season sequenced by two other nitrogen sources T2 and T4

\section{Chlorophyll a, b and carotenoids $\mathrm{mg} / \mathrm{g}$ f.w.}

In conducted to determine the chlorophyll $a, b$ and carotenoides content of leaves date palm under different nitrogen sources in (Table 3), it's appeared that T3 as $3 \mathrm{~g} / \mathrm{l}$ potassium nitrate proved the significant leave chlorophyll a contents $0.88 \mathrm{mg} / \mathrm{g}$ f.w. for $1^{\text {st }}$ season and $0.91 \mathrm{mg} / \mathrm{g}$ f.w for $2^{\text {nd }}$ season, graduated by two other nitrogen sources T2 as $5 \mathrm{~g} / \mathrm{l}$ ammonium sulfate $\left(0.85 \mathrm{mg} / \mathrm{g}\right.$ f.w. for $1^{\text {st }}$ season and $0.87 \mathrm{mg} / \mathrm{g}$ f.w. for $2^{\text {nd }}$ season) and T4 as $2 \mathrm{~g} / \mathrm{l}$ urea $\left(0.61 \mathrm{mg} / \mathrm{g}\right.$ f.w. for $1^{\text {st }}$ season and $0.65 \mathrm{mg} / \mathrm{g}$ f.w. for $2^{\text {nd }}$ season), the biggest significant of chlorophyll b contents came out under T3 recorded 0.45 and $0.46 \mathrm{mg} / \mathrm{g}$ f.w. for $1^{\text {st }}$ and $2^{\text {nd }}$ seasons respectively, whereas $\mathrm{T} 4$ had 0.28 and $0.30 \mathrm{mg} / \mathrm{g}$ f.w. for $1^{\text {st }}$ and $2^{\text {nd }}$ seasons respectively, lowest contents was achieved with control treatment, carotenoides leave contents were greatest with T3 produced 0.51 and $0.55 \mathrm{mg} / \mathrm{g}$ f.w. respectively for $1^{\text {st }}$ and $2^{\text {nd }}$ seasons, on the other hand sequenced results were found with two other nitrogen sources T2 and T4.

\section{Indole contents $\mathrm{mg} / \mathrm{g}$ f.w.}

It's appeared that results recorded in (Table 3) the indole leaves of date palm contents was significant varied from different nitrogen sources ammonium sulfate $\mathrm{T} 2$, potassium nitrate $\mathrm{T} 3$, urea $\mathrm{T} 4$, the treatment T3 resulted the majority for the higher indole contents 22.5 and $23.3 \mathrm{mg} / \mathrm{g}$ f.w. respectively in $1^{\text {st }}$ and $2^{\text {nd }}$ seasons in comparing other nitrogen sources, T2 recorded 19.4 and $20.4 \mathrm{mg} / \mathrm{g}$ f.w. and T4 had 17.4 and $18.1 \mathrm{mg} / \mathrm{g}$ f.w. with significant variance in between, meanwhile smallest contents of indole contents was achieved with control treatment.

\section{Proline mg/g d.w.}

It's to be come to light that, there were significant variance clarified among different nitrogen sources on the leaves proline contents (Table 3 ) compared to control treatments which caused the 
Table 1. Effect of different sources of nitrogen fertilizer on vegetative growth of date palm plantlet (Phoenix dactylifera L.) in the green house in the $1^{\text {st }}$ and $2^{\text {nd }}$ seasons

\begin{tabular}{|c|cccccccc|}
\hline \multirow{2}{*}{$\begin{array}{c}\text { Vegetative } \\
\text { growth }\end{array}$} & \multicolumn{2}{c|}{ Plant height (cm) } & \multicolumn{2}{c|}{ Leaves numbers } & \multicolumn{2}{c|}{ Root length (cm) } & \multicolumn{2}{c|}{ Roots numbers } \\
\cline { 2 - 10 } treatments & $\begin{array}{c}\text { first } \\
\text { season }\end{array}$ & $\begin{array}{c}\text { Second } \\
\text { season }\end{array}$ & $\begin{array}{c}\text { first } \\
\text { season }\end{array}$ & $\begin{array}{c}\text { Second } \\
\text { season }\end{array}$ & $\begin{array}{c}\text { first } \\
\text { season }\end{array}$ & $\begin{array}{c}\text { Second } \\
\text { season }\end{array}$ & $\begin{array}{c}\text { first } \\
\text { season }\end{array}$ & $\begin{array}{c}\text { Second } \\
\text { season }\end{array}$ \\
\hline T1 & 24.0 & 27.0 & 5.0 & 6.3 & 28.3 & 35.1 & 6.3 & 7.0 \\
T2 & 57.3 & 70.0 & 6.3 & 9.5 & 47.0 & 55.3 & 9.0 & 10.0 \\
T3 & 67.4 & 89.7 & 7.9 & 12.4 & 64.0 & 66.7 & 10.3 & 12.0 \\
T4 & 65.0 & 84.7 & 5.4 & 8.2 & 44.7 & 55.0 & 8.3 & 9.3 \\
\hline L.S.D. & $=1.9$ & $=3.8$ & $=2.1$ & $=3.3$ & $=4.7$ & $=4.0$ & $=0.9$ & $=1.0$ \\
\hline
\end{tabular}

Table 2. Effect of different sources of nitrogen fertilizer on fresh and dry weights of leaves and roots of date palm plantlets (Phoenix dactylifera $\mathrm{L}$ ) in the green house in the $1^{\text {st }}$ and $2^{\text {nd }}$ seasons

\begin{tabular}{|c|cccccccc|}
\hline $\begin{array}{r}\text { Vegetative } \\
\text { growth }\end{array}$ & \multicolumn{2}{|c}{$\begin{array}{c}\text { Leaves fresh } \\
\text { weight (g) }\end{array}$} & \multicolumn{2}{c}{$\begin{array}{c}\text { Leaves dry weight } \\
\text { (g) }\end{array}$} & \multicolumn{2}{c|}{$\begin{array}{c}\text { Root fresh weight } \\
\text { (g) }\end{array}$} & \multicolumn{2}{c|}{$\begin{array}{c}\text { Roots dry weight } \\
\text { (g) }\end{array}$} \\
\cline { 2 - 10 } treatments & $\begin{array}{c}\text { first } \\
\text { season }\end{array}$ & $\begin{array}{c}\text { Second } \\
\text { season }\end{array}$ & $\begin{array}{c}\text { first } \\
\text { season }\end{array}$ & $\begin{array}{c}\text { Second } \\
\text { season }\end{array}$ & $\begin{array}{c}\text { first } \\
\text { season }\end{array}$ & $\begin{array}{c}\text { Second } \\
\text { season }\end{array}$ & $\begin{array}{c}\text { first } \\
\text { season }\end{array}$ & $\begin{array}{c}\text { Second } \\
\text { season }\end{array}$ \\
\hline T1 & 2.3 & 2.6 & 0.9 & 1.2 & 2.1 & 2.4 & 0.6 & 0.8 \\
T2 & 5.8 & 6.4 & 2.5 & 3.1 & 3.6 & 3.9 & 1.1 & 1.8 \\
T3 & 6.7 & 7.4 & 2.9 & 3.3 & 3.8 & 4.9 & 1.5 & 2.0 \\
T4 & 5.5 & 6.6 & 2.4 & 2.8 & 2.4 & 2.7 & 0.6 & 1.5 \\
\hline L.S.D. & $=0.2$ & $=0.3$ & $=0.1$ & $=0.4$ & $=0.2$ & $=0.5$ & $=0.1$ & $=0.1$ \\
\hline
\end{tabular}

Table 3. Effect of different sources of nitrogen fertilizer on chlorophyll $a, b$ and carotenoides $\mathrm{mg} / \mathrm{g} \mathrm{f.w.,}$ indoles $\mathrm{mg} / \mathrm{g}$ f.w. and proline $\mathrm{mg} / \mathrm{g}$ d.w. of date palm plantlets (Phoenix dactylifera $\mathrm{L}$ ) in the green house in the $1^{\text {st }}$ and $2^{\text {nd }}$ seasons

\begin{tabular}{|c|cccccccccc|}
\hline \multirow{2}{*}{$\begin{array}{c}\text { Vegetative } \\
\text { growth }\end{array}$} & \multicolumn{2}{c}{$\begin{array}{c}\text { Chlorophyll a } \\
\mathbf{m g} / \mathbf{g} \text { f.w }\end{array}$} & \multicolumn{2}{c}{$\begin{array}{c}\text { Chlorophyll b } \\
\mathbf{m g} / \mathbf{g} \text { f.w }\end{array}$} & \multicolumn{2}{c|}{$\begin{array}{c}\text { Carotenoides } \\
\mathbf{m g} / \mathbf{g} \text { f.w }\end{array}$} & \multicolumn{2}{l|}{ Indoles $\mathbf{m g} / \mathbf{g}$ f.w. } & Proline $\mathbf{m g} / \mathbf{g}$ d.w. \\
\cline { 2 - 11 } treatments & $\begin{array}{c}\text { first } \\
\text { season }\end{array}$ & $\begin{array}{c}\text { Second } \\
\text { season }\end{array}$ & $\begin{array}{c}\text { first } \\
\text { season }\end{array}$ & $\begin{array}{c}\text { Second } \\
\text { season }\end{array}$ & $\begin{array}{c}\text { first } \\
\text { season }\end{array}$ & $\begin{array}{c}\text { Second } \\
\text { season }\end{array}$ & $\begin{array}{c}\text { first } \\
\text { season }\end{array}$ & $\begin{array}{c}\text { Second } \\
\text { season }\end{array}$ & $\begin{array}{c}\text { first } \\
\text { season }\end{array}$ & $\begin{array}{c}\text { Second } \\
\text { season }\end{array}$ \\
\hline T1 & 0.54 & 0.56 & 0.17 & 0.18 & 0.40 & 0.41 & 6.2 & 6.3 & 0.3 & 0.4 \\
T2 & 0.85 & 0.87 & 0.28 & 0.30 & 0.49 & 0.53 & 19.4 & 20.4 & 2.2 & 2.6 \\
T3 & 0.88 & 0.91 & 0.45 & 0.46 & 0.51 & 0.55 & 22.5 & 23.3 & 3.2 & 3.6 \\
T4 & 0.61 & 0.65 & 0.28 & 0.30 & 0.45 & 0.47 & 17.4 & 18.1 & 2.9 & 3.1 \\
\hline L.S.D. & $=0.02$ & $=0.03$ & $=0.03$ & $=0.04$ & $=0.01$ & $=0.01$ & $=1.2$ & $=1.4$ & $=0.1$ & $=0.1$ \\
\hline
\end{tabular}

little proline contents, greatest significant contents of proline was recorded with treatment T3 which increasing from $3.2 \mathrm{mg} / \mathrm{g}$ d.w. in $1^{\text {st }}$ season to 3.6 $\mathrm{mg} / \mathrm{g}$ d.w. for $2^{\text {nd }}$ season, meanwhile, $2.9 \mathrm{mg} / \mathrm{g}$ d.w. in $1^{\text {st }}$ season to $3.1 \mathrm{mg} / \mathrm{g}$ d.w. in $2^{\text {nd }}$ season given by treatment T4 graduated by T2 produced 2.2 and $2.6 \mathrm{mg} / \mathrm{g}$ d.w. respectively in $1^{\text {st }}$ and $2^{\text {nd }}$ seasons

\section{Leaves contents of N,P and K\%}

As shown in (Table 4) N, P and $\mathrm{K} \%$ leaves contents varied according to the sources of nitrogen fertilizer, mean values of $\mathrm{N}$ percent \% was graduated from T4, T3, T2 with differs among them, higher contents was scored 3.4 and $3.8 \%$ in the $1^{\text {st }}$ and $2^{\text {nd }}$ seasons under T4 as $2 \mathrm{~g} / \mathrm{l}$ urea, 
T3 as $3 \mathrm{~g} / \mathrm{l}$ potassium nitrate created 2.9 and $3.3 \%$ in the $1^{\text {st }}$ and $2^{\text {nd }}$ seasons, lowest nitrogen contents obtained by un fertilized plantlets (control treatment). Highest percent of phosphorus was appeared under T2 and T3 with no differences was found in between. Leaves potassium accumulation was highest in the $1^{\text {st }}$ and $2^{\text {nd }}$ seasons under T3 graduated by T4 treatment. Lowest potassium contents were found with control treatment.

\section{Root contents of N, P and K\%}

In relation to the root contents N,P and $\mathrm{K}$ percent \% (Table 4) root nitrogen percent was bringing highly with T3 as $3 \mathrm{~g} / \mathrm{l}$ potassium nitrate scored $2.3 \%$ in $1^{\text {st }}$ season to $2.6 \%$ in $2^{\text {nd }}$ season, while two other nitrogen sources were given 2.0 and $2.4 \%$ in the $1^{\text {st }}$ and $2^{\text {nd }}$ seasons respectively for $\mathrm{T} 2$ and 2.2 and 2.4 in the $1^{\text {st }}$ and $2^{\text {nd }}$ seasons for T4, the plantlets un received fertilizers showed the smallest percent of root nitrogen content. Highly phosphorus percent root content (Table 4) was related to the nitrogen source application that T3 and T4 compared with control treatment (un fertilized plantlets). Concerning the root potassium percent $\%$, the rising potassium contents given under T2 as $5 \mathrm{~g} / \mathrm{l}$ ammonium sulfate in the $1^{\text {st }}$ and $2^{\text {nd }}$ seasons, in compared to the other nitrogen sources T3 and $\mathrm{T} 4$, as well as control treatment had the smallest percent root potassium content.

\section{DISCUSSION}

Results on the date palm growth characteristics showed that, the different application of nitrogen sources which included the macronutrient NPK were produced healthy growth of date palm plantlets. The establishment and growth performance of nursery plants of several tree species is positively related to the amount of nitrogen $(N)$ reserves at planting. For this reason, increasing the amount of $\mathrm{N}$ reserves has become a goal of orchard and nursery management (Dong et al 2002), most compound fertilizers will contain three elements essential for plant growth: NPK which stands for nitrogen (promotes leaf growth, chlorophyll component, and it promotes vegetative growth and green colouration of foliage), phosphorus (root, flower, and fruit, plays a major role in photosynthesis, respiration, energy storage, cell division, and maturation), and potassium (stem and root growth and important in plant metabolism, protein synthesis (Chude et al 2004 and Remison 2005), fertilizers play an important role in increasing crop pro- duction. The main macronutrients present in inorganic fertilizers are nitrogen, phosphorus, and potassium which influence vegetative and reproductive phase of plant growth (Patil, 2010).

Date palm plantlets are much needed to fertilizers NPK in the acclimatization stage in the greenhouse for highly promote growth and possibility cultured them in the open field, date palm is a most important fruit crops. In Egypt, date palm ranked the third crop after orange and grape because of date palm can grow and produce under a wide rang of soil and climatic conditions, growers have mistakenly believed that it does not require much attention. The successful orchard management practices are directed toward obtaining a suitable yield with good fruit quality (Agric. Econ. Bull., 2005), Potassium is also an important nutrient for date palm growth and productivity (AlKharusi et al 2009), Potassium is necessary for basic physiological functions, such as the formation of sugars and starch, the synthesis of proteins, cell division and growth, fruit formation and could improve fruit size, flavour and colour (Abbas and Fares 2008).

Different vegetative growth of date palm were significant affected by application of various nitrogen sources potassium nitrate, urea, ammonium sulfate. The form of nitrogen applied can play a significant role in plant growth and productivity Ammonium $\left(\mathrm{NH}_{4}+\right)$, nitrate $\left(\mathrm{NO}_{3}-\right)$ and urea are the forms of nitrogen generally applied (Sady et al 2008). A balance of nitrate and ammonium nutrion is recommended for optimal plant growth, ammonium should not exceed $50 \%$ of the total nitrogen supply, and nitrate should not exceed $60 \%$ of total nitrogen supply (Charles 1998 and Fageria 2006)

Plant height $(\mathrm{cm})$, leaves numbers/plantlet (Table 1) scored higher significant increasing with potassium nitrate sequenced by urea, $920 \mathrm{~g} \mathrm{~N}+$ $700 \mathrm{~g} \mathrm{P} 2 \mathrm{O} 5$ + $1000 \mathrm{~g} \mathrm{K2O}$ increased number of strands/spathe of date palm cv. Dhakki (Muhammad et al 1992), $1300 \mathrm{~g}-4.5 \mathrm{Kg} /$ tree potassium sulfate, urea at $1300 \mathrm{~g}$ increased number of leaflet of date palm cv sayer (Diyalami and Garshasbi 2009), 38g/tree and urea (46\%) increased trees height, leaves numbers and branches length of peach tree (Jassim 2010), urea at 0.75 and $112.50 \mathrm{mg}$ increased significantly plant height and number of leaves of Khaya senegalensis African Mahogny (Focho et al 2011), urea at $180 \mathrm{Kg} / \mathrm{ha}$ and NPK at $361 \mathrm{Kg} / \mathrm{ha}$ increased plant height and number of leaves of (Glycin max L.) soybean (Yagoub et al 2012). 
Table 4. Effect of different sources of nitrogen fertilizer on leaves and roots $\mathrm{N}, \mathrm{P} \%$ and $\mathrm{K} \%$ of date palm plantlets (Phoenix dactylifera L.) in the green house in the first season $1^{\text {st }}$ and $2^{\text {nd }}$ seasons

\begin{tabular}{|c|cccccccccccc|}
\hline $\begin{array}{c}\text { Vegetative } \\
\text { growth }\end{array}$ & $\begin{array}{c}\text { Leaves } \\
\text { nitrogen } \\
\%\end{array}$ & \multicolumn{2}{c}{$\begin{array}{c}\text { Leaves } \\
\text { phosphorus } \\
\%\end{array}$} & \multicolumn{2}{c}{$\begin{array}{c}\text { Leaves } \\
\text { potassium } \\
\%\end{array}$} & $\begin{array}{c}\text { Roots } \\
\text { nitrogen } \\
\%\end{array}$ & $\begin{array}{c}\text { Roots } \\
\text { Phosphorus } \\
\%\end{array}$ & $\begin{array}{c}\text { Roots } \\
\text { Potassium } \\
\%\end{array}$ \\
\cline { 2 - 14 } & $\mathbf{1}^{\text {st }}$ & $\mathbf{2}^{\text {nd }}$ & $\mathbf{1}^{\text {st }}$ & $\mathbf{2}^{\text {nd }}$ & $\mathbf{1}^{\text {st }}$ & $\mathbf{2}^{\text {nd }}$ & $\mathbf{1}^{\text {st }}$ & $\mathbf{2}^{\text {nd }}$ & $\mathbf{1}^{\text {st }}$ & $\mathbf{2}^{\text {nd }}$ & $\mathbf{1}^{\text {st }}$ & $\mathbf{2}^{\text {nd }}$ \\
\hline T1 & 1.0 & 1.0 & 0.36 & 0.36 & 0.98 & 1.0 & 0.99 & 1.0 & 0.23 & 0.24 & 0.58 & 0.62 \\
T2 & 2.3 & 2.6 & 0.91 & 0.93 & 1.04 & 1.1 & 2.0 & 2.4 & 0.84 & 0.85 & 1.6 & 1.6 \\
T3 & 2.9 & 3.3 & 0.91 & 0.93 & 2.7 & 2.8 & 2.3 & 2.6 & 0.86 & 0.87 & 0.91 & 0.97 \\
T4 & 3.4 & 3.8 & 0.83 & 0.89 & 2.4 & 2.5 & 2.2 & 2.4 & 0.86 & 0.87 & 1.2 & 1.3 \\
\hline L.S.D. & $=0.4$ & $=0.6$ & $=0.01$ & $=0.01$ & $=1.6$ & $=1.3$ & $=0.2$ & $=0.1$ & $=0.02$ & $=0.01$ & $=1.1$ & $=1.1$ \\
\hline
\end{tabular}

Root length and numbers (Table 1) exhibited significant longest roots and greatest numbers under potassium nitrate followed by ammonium sulfate, these results reflected to the importance of potassium in root growth by enhancing carbohydrates formation of all plants, complete fertilizers NPK (ammonium nitrate, superphosphate P2O5 and potassium sulfate $48 \%$ ) increased root length and numbers (Waheed et al 2001 on tea trees (Camellia sinensis), $100 \mathrm{Kg} \mathrm{N} / \mathrm{ha}, 60 \mathrm{Kg} / \mathrm{ha}$ of $\mathrm{P}_{2} \mathrm{O}_{5}$ and $30 \mathrm{Kg} / \mathrm{ha}$ of $\mathrm{K}_{2} \mathrm{O}$ increased root length of Amaring anthus curentus (Akande, 2006), potassium sulfate at $125 \mathrm{~g}$ as $48 \% \mathrm{~K}_{2} \mathrm{O}, 387.1 \mathrm{~g}$ as 15.5 $\mathrm{P}_{2} \mathrm{O}_{5}$ (calcium superphosphate) and urea $46 \%$ at 391.3 increased roots numbers of Senna occidentalis ( Kamel and Weam 2009).

Fresh and dry weights of leaves and roots affected by different nitrogen sources, the highest weights of leaves as fresh and dry was found with potassium nitrate T3 succeeded by urea T4 and ammonium sulfate T2. Increasing of fresh weights of leaves and roots of saffron (Crocus sativus L.) under different sources of nitrogen as ammonium nitrate and sulfate, urea and calcium ammonium nitrate (Mesude and Aysun, 2005), N have a strong effect on various growth parameters, such as biomass and yield (Salvagiotti and Miralles 2008), potassium sulfate and $\mathrm{P}_{2} \mathrm{O}_{5}$ increased fresh weight of roots of (Rhapis excelsa) lady palm (Petterson et al 2008), $120 \mathrm{Kg} \mathrm{N} / \mathrm{ha}$ increased fresh and dry weights of peach leaves Prunus persica $\mathrm{L}$. (Xavier, 2010), Recently, ammonium nitrate 33\% $\mathrm{N}$ and urea increased fresh and dry weights (Ibrahim on Datura innoxia Mill 2013 and Priyadarshani et al on Vetiver (Vetiveria zizanioides L.) 2013).

As for the chemical characteristics, chlorophyll $a, b$ and carotenoides contents which have the main role of photosynthesis process and formation of carbohydrates and other important substances for plant life, data (Table 3) showed significant effect for different applications of nitrogen sources. Moreover, the nitrogen source as potassium nitrate performed the greatest contents of chlorophyll a,b and carotenoides sequenced by ammonium sulfate and urea, 33\% N and NPK increased chlorophyll contents significantly (Baset Mia et al 2009 on banana and Ebtihaj, 2012 on date palm cv Barhi), urea $46 \%$ N (200 kg/hat) increased chlorophyll contents of Solanum tuberosum L (Taha, 2010), urea at $1 \mathrm{Kg} /$ tree, $350 \mathrm{gr} /$ tree $\mathrm{P}_{2} \mathrm{O}_{5}$ and $450 \mathrm{gr} /$ tree potassium sulfate significant greatest the chlorophyll content (Ayad, 2010 on peach Prunus persica L. and Bybordi, 2013 on apricot Prunus armeniaca),

Indoles contents (Table 3) was found higher under potassium nitrate and urea with significant differs in between, these results attributed to the important of nitrogen in the protein metabolism process in which reflected in strongly increased key enzyme activities and improved indoles metabolism in the plant cell which involved to all plant build up, $33 \% \mathrm{NH}_{4} \mathrm{NO}_{3}, \mathrm{P}_{2} \mathrm{O}_{5}$ and potassium sulphate increased contents of indoles (Darwesh 2010 on Phoenix dactylifera L. cv medjol).

The proline contents (Table 3 ) was significantly affected by potassium nitrate sequenced by urea, The higher protein content of $\mathrm{N}$ treated plants could be related with the positive effect of $N$ on some important physiological processes (Chaturvedi 2005), $20 \mathrm{mM} \mathrm{N}$ from $\mathrm{NH}_{4} \mathrm{NO}_{3}$ increased protein contents of 'Fuji'apple (Malus domestica Borkh.) trees on M.26 rootstock (Cheng et al 2004), $\mathrm{N}$ at $45 \mathrm{Kg} / \mathrm{ha},\left(\mathrm{NH}_{4}\right) \mathrm{NO}_{3}$, Urea and P2O5 increased proteins contents (Akanbi et al 2007 on Telfairia occidentalis, Omar 2010 on Solanum tuberosum and Khalid 2012 on anise (Pimpinella anisum L.). 
These results from the $\mathrm{N}, \mathrm{P}$ and $\mathrm{K}$ percent leaves and root content (Tables 4$)$ give an explanation for the highest percent contents in the leaves above the roots contents, these notice showed that highest contents of macronutrients in the leaves in which its fast transformation from roots to leaves to used these nutrients in all bio process and photosynthesis process in the plants. Nitrate is taken up by roots and is immediately moved upward in the plant to the stems and leaves, the plant must convert the nitrate to ammonium, which it does with nitrate reductase enzymes, the conversion is done in the stems and leaves, young plants have not developed the nitrate reductase enzyme yet as soon as the plants were olderd have immediate movement of nitrate into the leaves (Charles, 1998), potassium sulfate and $\mathrm{P}_{2} \mathrm{O}_{5}$ and ammonium sulfate increased the contents of $\mathrm{P}$ and $\mathrm{K}$ of Citrus (Citrus aurantium Lush) cv. Ponkan (He et al. 2000 on (white marsh) grape, Yang, 2000 on citrus and Johnson et al on Peach 2001), Potassium sulfate, and ammonium sulfate increased $\mathrm{N}, \mathrm{P}$ and $\mathrm{K}$ of date palm crs. Barhi and Bartomouda (Harhash and AbdelNaser 2007, Osman 2010 and Al-Kahtani and Soliman, 2012).

\section{REFERENCES}

Abbas, F. and A. Fares 2008. Best management practices in citrus production. Tree For. Sci. Biotech. 3: 1-11.

Abdi, G.H. and M. Hedayat 2010. Yield and fruit physiochemical characteristics of 'Kabkab' date palm as affected by methods of potassium fertilization. The Free Library Science and Technology, www.google.com.

Agricultural Economic Bulletin 2005. Ministry of Agriculture and Land Reclamation, A.R.E., Acreage and total production of fruits (in Arabic), p.177.

Akanbi, W.B., C.O. Adebooye, A.O. Togun, J.O. Ogunrinde and S.A. Adeyeye 2007. Growth, Herbage and Seed Yield and Quality of Telfairia occidentalis as Influenced by Cassava Peel Compost and Mineral Fertilizer. World Journal of Agricultural Sciences, 3(4): 508-516.

Akande, M.O. 2006. Effect of organic root plus (biostimulant) on the growth, nutrient content and yield of amaranthus. African Journal of Biotechnology, 5(10): 871-874.

Al-Kahtani, S.H. and S.S. Soliman 2012. Effects of organic manures on yield, fruit quality, nutrients and heavy metals content of Barhy date palm cultivar. African Journal of Biotechnology, 11(65): 12818-12824.

Al-Kharusi, L.M., M.O. Elmardi, A. Ali, F. AlJulanda, L. Al-Said, K. Abdelbasit, J.M. AlAlpha, J. Chen and G. Zhang 2009. Effect of nitrogen fertilizer forms on growth, photosynthesis, and yield of rice under cadmium stress. J. Plant Nutrition, 32(2): 306-317.

Ayad, T.M.S.A. 2010. Effect of nitrogen and Gibberellic acid on the growth of young peach trees cv. Dixired. Iraqi Academic Scientific Journal, 38: 118-126.

Bybordi, A. 2013. Quantitative and Qualitative Effects of Nutrient Applications and Irrigation Methods on Apricot. Middle-East Journal of Scientific Research 14(3): 423-431.

BasetMia, M.A., Z.H. Shamsuddin,; Z. Wahab and $M$. Marziah 2009. The effect of rhizobacterial inoculation on growth and nutrient accumulation of tissue-cultured banana plantlets under low $\mathrm{N}$-fertilizer regime. African Journal of Biotechnology, 8(21): 5855-5866.

Bates, L.E., R.P. Waldren and I.D. Teare 1973. Rapid determination of free proline for water stress studies. Plant and Soil 39: 205-207.

Britto, D.T. and H.J. Kronzucker 2002. $\mathrm{NH}_{4}^{+}$toxicity in higher plants: a critical review. Journal of Plant Physiology, 159: 567-584.

Carrington, M.E., M.O. Hampton and J.J. Mullahey 2000. Effect of nitrogen fertilization on Saw palmetto (Serenoa repens). Hort. Science, 30 (30): 455-456.

Chaturvedi, I. 2005. Effect of nitrogen fertilizers on growth, yield and quality of hybrid rice (Oryza sativa). J. Centl. Eur. Agric. 6(4): 611-618.

Charles, M.B.P.E. 1998. Chemicals for fertigation. Proceedings of International Irrigation Show. IAs 19th Annual Conference, Nov. 1-3, San Diego.

Cheng, L., M.A. Fengwang and R. Damayanthi 2004. Nitrogen storage and its interaction with carbohydrates of young apple trees in response to nitrogen supply. Tree Physiology 24: 91-98.

Chude, V.O., W.B. Malgwi, I.V. Amapu and O.A. Ano 2004. Manual on Soil Fertilit Assessment, Federal Fertilizer Department (FFD), Abuja, Nigeria.

Darwesh, R.S.S. 2010. Phoenix dactylifera cv. Medjol plantlets as affected by yeast extract and NPK fertilizers. The Six International conference of Sustainable Agriculture Development,27-29 Dece. pp 115-130. 
Diyalami, H. and M.R. Garshasbi 2009. Study on the effect of different amounts application of NPK on quantitative and qualitative characteristics of date palm cv "Sayer" in Khuzestan Province. AGRIS- FAO of the United Nations. www.google.com.

Dong, S., L. Cheng, C.F. Scaqel and L.H. Fuchigami 2002. Nitrogen absorption, translocation and distribution from urea applied in autumn to leaves of young potted apple (Malus domestica) trees. Tree Physiol., 22(18): 1305-1310.

Ebtihaj, H.A.T. 2012. Effect of addition of equivalent ratio of mechanical fertilizers on growth of date palm (Phoenix dactylifera L) Barhi cv. Barsa Science Journal, 4 (38):60-73.

Fageria, N.K. 2006. The Use of Nutrients in Crop Plants. CRC Press. www .google.com

FAO. 2010. Food and Agriculture Organization of the United Nations.www.google.com

Focho, D.A., E. Bechem, E. Andrew, F.A. Genla, F.B. Ambo and N.R. Ndah 2011. Effects of organic and inorganic fertilizers on early growth characteristics of Khaya ivorensis Chev (African mahogany) in nursery African Journal of Plant Science, 5(12): 722-729.

Harhash, M.M. and G. Abdel-Nasser 2007. Impact of potassium fertilization and bunch thinning on zaghloul date palm. The Fourth Symposium on Date Palm in Saudi Arabia, King Faisal Univ. Alahsa, 5-8 May.

He, Z.L., D.V. Calvert; A.K. Alva and Y.C. Li 2000. Effects of fertilizer rates on fruit quality of (white marsh) grape fruit in a sandy soil. Hort. Science, 35 (3), p. 454.

Ibrahim, O.A.A. 2013. Effect of chemical and biofertilizers on growth and chemical constituents of datura (Datura innoxia Mill.) plants. Ms. Thesis. Hort. Dept., Fac. Agric., Fayoum Univ. Nig. Limited. Benin City. p. 170.

Iqbal, M., A. Ghafoor and S. Rahman 2004. Effect of pollination times on fruit characteristics and yield of date palm cv. Dhakki. Int. J. Agric. Biol. 6: 96-99.

Jackson, M.L. 1973. Soil Chemical Analysis. Printica-Hall of India, Private Limited, New Delhi.

Jassim, M.A.A. 2010. Effect of organic fertilizer, urea and sulphur on vegetative growth and concentration of some nutrient of young Peach trees cv. Dixired. Tikrit University Journal of Agricultural Sciences, 2 (10): 76-86.

Johnson, R.S., R. Rosecrance, H. Andris and J. Wang 2001. Can We Approach Complete Dependence on Foliar applied Urea Nitrogen in an
Early-maturing Peach. J. Amer. Soc. Hort. Sci., 126(3): 364-370.

Kamel, M.M. and R.S. Weam 2009. Response of Senna occidentalis, Link plants to fertilization as well as Citric acid and their role in remediating soil polluted with $\mathrm{Cu}$ and $\mathrm{Pb}$. World Journal of Agricultural Science, 5(6): 784-798.

Kassem, H.A. 2012. The response of date palm to calcareous soil fertilization. Journal of Soil Science and Plant Nutrition, 12 (1): 45-58.

Khalid, K.A. 2012. Effect of NP and foliar spray on growth and chemical compositions of some medicinal Apiaceae plants grow in arid regions in Egypt. Journal of Soil Science and Plant Nutrition, 12 (3): 581-596.

Kim, T., H.A. Mills and H.Y. Wetzstein 2000. Studies on the effects of nitrogen sources on pecan nutrient uptake and plant growth and development. Hort. Science, 30(3), p. 455.

Larsen, P., A. Harbo, S. Klungroun and T. Ashein 1962. On the biogenesis of some indole compounds in Acetobacter xylinum. Physiol Plant ,15: 552-565.

Li, H., R. Gordon, R. Lada, S. Asiedu and N. Goodyear 2007. Development of high plant population seeding technology: Double-row direct seeding for Brassica vegetables. Abstract of Atlantic Agricultural Science and Communication Workshop. Truro, NS: p. 18.

Lichtenthaler, H.K. and A.R. Wellburn, 1985. Determination of Total Carotenoids and Chlorophylls A and B of Leaf in Different Solvents. Biol. Soc. Trans. 11: 591-592.

Marschner, H. 1995. Mineral nutrition of higher plants. Academic Press: Harcourt Brace Jovannovich, Publishers. London, San Diego, New York and Tokyo, p. 673.

Martinez-Ballestra, M.C., L. Lopez-Perez, M. Hernandez, C. Lopez-Berenguer, N. Fernandez-Garcia and M. Carvajal 2008. Agricultural practices for enhanced human health. Phytochemical Reviews, 7: 251-260.

Mehedi, T.A., M.A. Siddique and S.B. Shahid 2012. Effects of urea and cowdung on growth and yield of carrot. Journal of Bangladesh Agril. Univ. 10(1): 9-13.

Mesude, U.N.A.L. and C. Aysun 2005. The effect of various nitrogen fertilizers on Saffron (Crocus sativus L.) yield. Akdeniz Universitesi Ziraat Fakultesi Dergisi, 18(2): 257-260.

Muhammad, M., U.D.B. Jalal, A.A. Atiq and A. Zia 1992. Response of date cultivar Dhakki to NPK fertilizers in D.I. Khan. Pakistan J. Agric. Res. 1,3(4): 347-349. 
Omar, K.H. 2010. The Effect of Inoculation With Azotobacter Bacteria and Different Levels of Nitrogen Fertilizer on 2-Production of Potato plant (Solanum tuberosum L). Iraq Academic Scientific Journals Conference, 38: 5-10.

Osman, S.M. 2010. Effect of Potassium Fertilization on Yield, Leaf Mineral Content and Fruit Quality of Bartamoda Date Palm Propagated by Tissue Culture Technique under Aswan Conditions. Journal of Applied Sciences Research, 6(2): p.184.

Patil, N.M. 2010. Biofertilizer Effect on Growth, Protein and Carbohydrate Content in Stevia Rebaudiana Var Bertoni. Recent Research In Science And Technology, 2(10): 42-44.

Petterson, B.D.L., D.D.O.P. Patr'Icia and R.T. Armando 2008. Effect of Foliar and Substrate Fertilization on Lady Palm Seedling Growth and Development. Journal of Plant Nutrition, 31: 1311-1318.

Priyadarshani, N.D.N., M.K.T.K. Amarasinghe, S. Subasinghe, I.R. Palihakkara and H.K.M.S. Kumarasinghe 2013. Effect of organic and inorganic fertilizers on biomass production, oil yield and quality of vetiver (Vetiveria zizanioides L.). The Journal of Agricultural Sciences, (8): 28-35.

Remison, S.U. 2005. Basic Principles of Crop Physiology. Sadoh Press Nig, Benin City, pp. 1-170.

Ruan, J.Y., J. Gerendas, R. Harder and S. Burkhard 2007. Effect of nitrogen form and root zone $\mathrm{PH}$ on phosphorus source on growth and nitrogen uptake of Camellia sinensis L. Plant and Soil. 223: 65-73.

Sady, W., S. Rozek, I. Domagala-Swiatkiewicz, R. Wo-jciechowska and A. Kolton 2008. Effect of nitrogen fertilization on yield, $\mathrm{NH}_{4}$ and $\mathrm{NO}_{3}{ }^{-}$content of white cabbage. Acta Sci. Pol., Hortorum Cul- tus, 7: 41-51.

Saleh, J.2009. Yield and chemical composition of 'Piarom' Date-Palm Phoenix dactylifera L. as affected by nitrogen and phosphorus Levels.
International Journal of Plant Production 3(3): 57-64.

Salvagiotti, F. and D.J. Miralles 2008. Radiation interception, biomass production and grain yield as affected by the interaction of nitrogen and sulfur fertilization in wheat. Europ. J. Agron., 28: 282-290.

Sarfaraz, F.A.A. 2010. Effect of some chemical compounds on some characteristics of shoot and fruit of peach (Prunus persica L.) cv. Early coronet, Iraqi Academic Scientific Journal, 38: 198-204.

Snedecor, G.W. and W.G. Cochran 1980. Statistical Methods. $11^{\text {th }}$ Ed. lowa State Univ., Press. Ames, lowa, USA.

Shimbo, S., T. Watanabe, Z.W. Zhang and M. Ikeda 2001. Cadmium and lead contents in rice and other cereal products in Japan in 19982000. Sci. Total Environ. 281: 165-175.

Taha, Z.S. 2010. The effect of inoculation with azotobacter bacteria and different levels of nitrogen fertilizer on 1-vegetative growth of potato plant (Solanum tuberosum L.). Iraq Academic Scientific Journals Conference, 38: 510.

Waheed, A., A. Jamal, F.S. Hamid and N. Ahmed 2001. Growth of Tea seedlings affected by different levels and application methods of NPK and urea. Online Journal of Biological Science, 1(3): 101-102.

Xavier, D.M. 2010. Effects of irrigation and nitrogen application on vegetative growth, yield and fruit quality in peaches (Prunus persica L. Batsch cv. Andross) for processing. Ph. Thesis, Unuversitate de Lleida, p. 17.

Yagoub, S.Y., W.M.A. Ahmed and A.A. Mariod 2012. Effect of Urea, NPK and Compost on Growth and Yield of Soybean (Glycine max L.), in Semi-Arid Region of Sudan. International Scholarly Research Network, 2012: 1-6.

Yang, X.E., X.Y. Lin, Y.S. Zhang and E.W. Stover 2000. Balanced nutrient management in citrus grown in acid red soils of Southeast China. Hort. Science, 35(3): 454. 